Case control study

\title{
Polymorphisms in the Mn-SOD and EC-SOD genes and their relationship to diabetic neuropathy in type I diabetes mellitus Dimitry A Chistyakov ${ }^{* 1}$, Kirill V Savost'anov ${ }^{2}$, Elena V Zotova ${ }^{2}$ and Valery V Nosikov $^{2}$
} Address: ${ }^{1}$ INSERM U36, College de France, 75231 Paris Cedex 05, France and ${ }^{2}$ Department of Molecular Diagnostics, National Research
Center GosNIIgenetika, Moscow 113545, Russia

E-mail: Dimitry A Chistyakov* - dimitry.chistiakov@eudoramail.com; Kirill V Savost'anov - kir_savostianov@yahoo.com; Elena V Zotova - lena-zotova@mail.ru; Valery V Nosikov - nosikov@genetika.ru

*Corresponding author

Published: 28 March 2001

BMC Medical Genetics 200I, 2:4

This article is available from: http://www.biomedcentral.com/I47I-2350/2/4

(c) 200 I Chistyakov et al, licensee BioMed Central Ltd.
Received: 20 December 2000

Accepted: 28 March 2001

\begin{abstract}
Background: Oxidative stress, resulting in a marked increase in the level of oxygen free radicals (OFR), has been implicated in the etiology of diabetic neuropathy (DN). Antioxidant enzymes may protect against the rapid onset and progression of $D N$, by reducing the excess of OFR and peroxide. Mutations and polymorphisms in the genes encoding such enzymes may therefore result in predisposition to $\mathrm{DN}$. We investigated the role of genes encoding two antioxidant enzymes, mitochondrial (Mn-SOD) and extracellular (EC-SOD) superoxide dismutase, in DN pathogenesis in a Russian population. We studied $\mathrm{Ala}(-9) \mathrm{Val}$ and lle58Thr polymorphisms of the Mn-SOD gene and Arg2/3Gly dimorphism of the EC-SOD gene in type I diabetic patients with $(n=82)$ and without DN $(n=84)$.

Results: We developed and used a new polymerase chain reaction (PCR) assays for rapid detection of polymorphisms. These assays involved the use of mismatch PCR primers to create restriction sites in the amplified product only in presence of the polymorphic base. The PCR product was than digested with BshTI, Eco32I or Eco52I to detect Ala(-9)Val, lle58Thr or Arg2 I 3Gly polymorphic site respectively. The frequencies of the Ala allele $(50.6 \%$ vs. $68.5 \%, p<0.002)$ and the Ala/Ala genotype $(17.1 \%$ vs. $39.3 \%, p<0.005)$ of the $M n-S O D$ gene were significantly lower in DN patients than in diabetic subjects without $D N$. In contrast, the Val allele $(49.4 \%$ vs. $31.5 \%, p<$ $0.002)$ and the $\mathrm{Val} / \mathrm{Val}$ genotype $(\mathrm{I} 5.9 \%$ vs. $2.4 \%, \mathrm{p}<0.0 \mathrm{I})$ were significantly more frequent in the DN patients than in the control group.
\end{abstract}

Conclusions: Ala(-9) Val substitution in the Mn-SOD gene was associated with DN in a Russian population

\section{Background}

Oxidative stress has been implicated in the etiology of long-term diabetic complications, including peripheral neuropathy [1]. Oxygen free radicals (OFR) may damage neurons by causing nerve lipid peroxidation, the break- down of mitochondrial DNA and inhibition of the respiratory chain, and the cross-linking of the neurofilament protein [2-4]. Treatment with antioxidants (e.g. probucol, alpha-lipoic acid) decreases lipid peroxidation and oxidative stress in neural tissues and improves the con- 
dition of rats with streptozotocin-induced diabetic neuropathy $[5,6]$.

Antioxidant enzyme activity is low in peripheral nerves and even lower in diabetic nerves, possibly due non-enzymatic glycation and autooxidation of the glycated protein $[7,8]$. Antioxidant enzymes may protect against the rapid onset and progression of diabetic neuropathy (DN) by reducing the excess of both OFR and peroxide. Defects and mutations in the genes encoding these enzymes may therefore lead to suspectibility to DN.

Superoxide dismutase (SOD) is the key antioxidant enzyme involved in the detoxication of superoxide radicals. SOD is a metalloprotein and its manganese form (MnSOD) is present in mitochondria. Two other forms containing cooper and zinc (CuZn) have cytoplasmic or extracellular (EC-SOD) location.

An alanine (GCT) to valine (GTT) substitution at position -9 in the signal peptide of human Mn-SOD has been shown to change the structural conformation of the mitochondrial targeting sequence of the enzyme. This substitution may lead to misdirected intracellular trafficking, followed by changes in Mn-SOD activity in the mitochondria $[9,10]$. Associations have been found between the Ala(-9)Val dimorphism in the SOD2 gene and such human neurodegenerative and ageing disorders as Parkinson's disease [9], tardive dyskinesia [11], sporadic motor neuron disease [12], and nonfamilial idiopathic dilated cardiomyopathy [13].

The Ile58Thr amino acid exchange destabilizes the tetrameric interface of Mn-SOD and reduces its enzymatic activity [14]. This finding suggests that the Ile58Thr polymorphism may be associated with neurodegenerative diseases involving a decrease in Mn-SOD levels [15]. However, no association between the Ile58Thr polymorphism and Parkinson's disease was found in German patients [16].

Extracellular superoxide dismutase (EC-SOD) has an amino acid substitution Arg213Gly in the heparin-binding domain [17]. The glycine variant of the enzyme is responsible for high EC-SOD levels in serum $[18,19]$ that are correlated with a decrese in nitric oxide production in epithelial cells [20] and various other metabolic cardiovascular risk factors [21]. A relationship was found between the Arg213Gly dimorphism and familial amyloidotic (non-diabetic) neuropathy in a Japanese population, involving greater dissociation of EC-SOD from the vascular wall followed by extensive oxidative stress and cardiac, renal, and autonomic nervous system failure due to massive amyloid deposition [22].
In this study, we investigated whether allelic variants of the $M n-S O D$ and $E C-S O D$ genes were involved in the etiology of DN in Russian type 1 diabetic patients. To do this, we developed new methods for the simple and rapid detection of polymorphisms in the $M n-S O D$ and $E C-S O D$ genes.

\section{Materials and Methods Subjects}

In this study, 88 healthy Russian donors selected at random (59 males and 29 females, mean age $28.3 \pm 8.4$ years, mean \pm SEM) were examined. Healthy subjects had no autoimmune, cardiovascular, or other diseases. All study participants lived in Moscow or the Moscow region. Blood samples were collected in the Department of Endocrinology and Diabetology of the Russian Academy for Advanced Medical Studies. This study was approved by the Academy Review Board and was carried out in accordance with the principles of the second Helsinki Declaration. Informed consent was obtained from all subjects before participation in this study.

We studued a total of 166 genetically unrelated Russian patients affected with type 1 diabetes mellitus (97 males and 69 females, mean age 25.0 \pm 13.4 years, mean duration of diabetes $9.6 \pm 9.2$ years). None of the patients studied were treated with antioxidants. Patients with causes of neuropathy other than diabetes (e.g. chronic alcohol abuse, drug-induced neuropathy), truncal neuropathy, and significant neurological diseases (e.g. Parkinson's disease, epilepsy, multiple sclerosis) were excluded from the association study. DN was diagnosed on the basis of symptomatic symmetrical distal neuropathy (reduced/absent ankle reflexes, reduced vibration, thermal, tactile, pin-prick, and/or position sensation) with one or more typical symptoms (burning pains or cramps, paresthesiae, numbness) of at least moderate severity in the feet. DN patients were also identified by measuring the motor conduction velocity of the peroneal nerve, with a velocity of $<42 \mathrm{~m} / \mathrm{s}$ (mean $31.6 \pm 1.0 \mathrm{~m} / \mathrm{s}$ ) used to identify patients with DN. Accompanying retinopathy was diagnosed based on the presense of microaneurysms together with hard exudates and retinal hemorrhages, new vessel formation and/or fibrous retiniis proliferans Clinical nephropathy was diagnosed on basis of persistent proteinuria (urinary protein excretion rate $>0.3 \mathrm{~g} / 24 \mathrm{~h}$ ). The 166 patients tested were assigned to two groups according to the duration of diabetes. The groups were formed using principal of extreme phenotype and nonoverlapping selection criteria to minimize the masking effects of non-genetic factors. The first group consisted of 82 patients with diabetes of short duration ( $<3$ years) and DN. The other group contsisted of the remaining 84 diabetic patients, all of whom had diabetes of long duration ( $>10$ years) and no neuropathy. 
The characteristics of the two groups are shown in Table 1.

Table I: Clinical characteristics of the patients

\begin{tabular}{lcc}
\hline \multicolumn{1}{c}{ Characteristic } & $\begin{array}{c}\text { Neuropathy } \\
(\mathrm{n}=82)\end{array}$ & $\begin{array}{c}\text { No neuropathy } \\
(\mathrm{n}=84)\end{array}$ \\
\hline Sex (male/female) & & \\
Age (years) & $48 / 34$ & $49 / 35$ \\
Duration of diabetes (years) & $23.5 \pm 14.3$ & $32.1 \pm 14.2$ \\
Glycated haemoglobin, HbA, (\%) & $1.1 \pm 0.9$ & $20.1 \pm 8.4$ \\
Retinopathy & $10.6 \pm 3.0$ & $10.8 \pm 3.8$ \\
Nephropathy $^{\mathrm{a}}$ & 31.7 & 92.8 \\
& 2.4 & 59.5 \\
\hline
\end{tabular}

Values are mean \pm SEM or ${ }^{\text {a }}$ percentage of patients

\section{Genomic DNA isolation and genotyping of Mn-SOD}

DNA was extracted from whole human blood with phenol and chloroform [23]. Polymorphic regions were amplified by polymerase chain reaction (PCR) in $50 \mu \mathrm{l}$ reaction mixture consisting of $67 \mathrm{mM}$ Tris- $\mathrm{HC} 1$ ( $\mathrm{pH} 8.8$ ), $16.7 \mathrm{mM}$ ammonium chloride, $1.0 \mathrm{mM}$ magnesium chloride, $0.1 \%$ Tween-20, 10\% dimethyl sulfoxide, $0.2 \mathrm{mM}$ of each dNTP, 5 pmol of each primer, 100 ng of genomic DNA, and 2.5 units of Taq polymerase (Biotekh, Russia). To amplify the polymorphic Ala(-9)Val region, we used primers SOD2-16F 5'-CCAGCAGGCAGCTGGCACCG-3' and SOD2-16R 5'-TCCAGGGCGCCGTAGTCGTAGG-3'. For the polymorphic Ile58Thr region of the $M n-S O D$ gene, PCR primers SOD2-58F 5'-AAGCTCCTCCCATTATCTAATAGC-3' and SOD2-58R 5'-TCAGTGCAG-
GCTGAAGAGAT-3' were used. PCR was carried out in a PHC-2 thermal cycler (Techne, UK) with 35 cycles of denaturation for $1 \mathrm{~min}$ at $94^{\circ} \mathrm{C}$, annealing for $1 \mathrm{~min}$ at $55^{\circ} \mathrm{C}$ (Ile58Thr) or $60^{\circ} \mathrm{C} \mathrm{(Ala(-9)Val),} \mathrm{and} \mathrm{extension} \mathrm{for} 1 \mathrm{~min}$ at $72^{\circ} \mathrm{C}$.

To detect Ala(-9)Val dimorphism, the PCR product was digested with BshTI. For the Ile58Thr polymorphism, the amplified fragment was digested with Eco32I (both enzymes from Fermentas, Lithuania). For digestion, 17 $\mu \mathrm{l}$ of PCR product, $2 \mu \mathrm{l}$ of buffer $\mathrm{O}^{+} /$Tango $^{\mathrm{TM}}$ (BshTI) or $\mathrm{R}^{+} /$Tango $^{\mathrm{TM}}$ (Eco32I) (all buffers from Fermentas, Lithuania), and $1 \mu \mathrm{l}$ of restriction endonuclease (1 unit/ $\mu \mathrm{l})$ were mixed and incubated for $12 \mathrm{~h}$ at $37^{\circ} \mathrm{C}$. Digested DNA products were separated by electrophoresis in a $3 \%$ agarose gel with ethidium bromide or in an $8 \%$ polyacrylamide gel stained with silver [24].

\section{Genotyping of Arg2 I 3 Gly EC-SOD}

The polymorphic region was amplified in a $50 \mu \mathrm{l}$ reaction mixture consisting of $10 \mathrm{mM}$ Tris- $\mathrm{HCl}(\mathrm{pH} \mathrm{8.8),} 50 \mathrm{mM}$ $\mathrm{KCl}, 1.5 \mathrm{mM}$ magnesium chloride, $0.1 \%$ Tween-20, $10 \%$ dimethyl sulfoxide, $0.2 \mathrm{mM}$ of each dNTP, $5 \mathrm{pmol}$ of each primer SOD3-213F 5'-GGCTGGCCTGCTGCGTGGTGG$3^{\prime}$ and SOD3-213R 5'-CCTTGCACTCGCTCTCGCGCG-3', $100 \mathrm{ng}$ of genomic DNA, and 2.5 units of Taq polymerase. The PCR cycling profile was as described above except that annealing was carried out for $1 \mathrm{~min}$ at $65^{\circ} \mathrm{C}$. The amplicon was cleaved with restriction endonuclease Eco52I (Fermentas, Lithuania) in Eco52I+ specific buffer according to the manufacturer's recommendations. Digested fragments were analyzed as described by electrophoresis for the genotyping of $M n-S O D$.

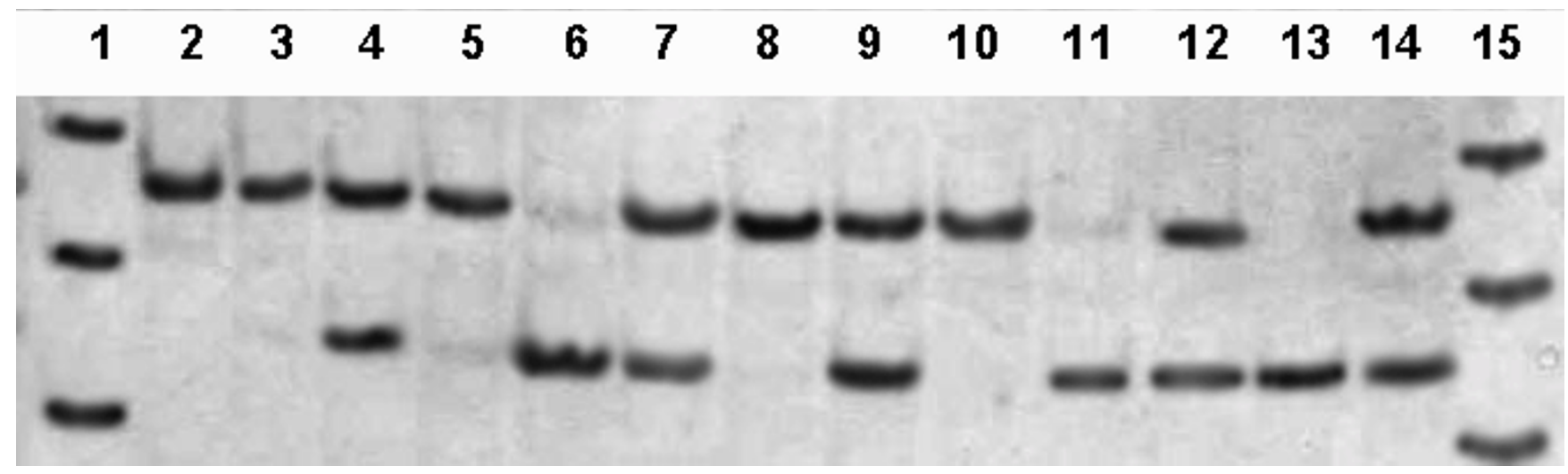

\section{Figure I}

Restriction analysis of Ala(-9)Val polymorphism in the SOD2 gene. Lanes 2- I4: I 3 samples after digestion with BshTI; lanes 2, 3, 5, 8, and I0, Ala/Ala genotype; lanes 4, 7, 9, I2, and I4, Ala/Val genotype; lanes 6, II, and I3, Val/Val genotype. Lanes I and I5: molecular weight DNA marker $\phi \times 174 /$ Hinfl 100-, 82- and 60-bP DNA fragments are shown. 


\section{Statistical analysis}

Genotype frequencies were checked for deviation from Hardy-Weinberg equilibrium by the $\mathrm{X}^{2}$ and G-statistic tests, using the Rows and Columns program based on the Roff and Bentzen algorithm [25]. Genotype and allele frequencies in the groups studied were compared by Fisher's exact test The $p$ value was corrected by multiplying it by the number of alleles (2) for each locus to obtain the $\mathrm{p}_{\mathrm{c}}$ value. Odds ratios and 95\% confidence interval (95\% CI) were calculated to assess the strength of the relationship between the $M n-S O D$ or $E C-S O D$ polymorphisms and DN.

\section{Results}

The Ala(-9) Val polymorphism of the Mn-SOD gene

The first adenosine residue from 3 'end of the forward primer, SOD2-16F, is mismatched with genomic DNA. The original sequence, near the polymorphic site of the Mn-SOD gene, is 5'-TCCGGT-3' with the most variable $3{ }^{\prime}$ thymidine (Val) to cytidine (Ala) at position -9 [26]. Use of the mismatched primer, SOD2-16F, results in a 91-bp PCR product. This product may or may not contain a BshTI restriction site ( 5 '-ACCGGT-3'), depending on the sequence. If the -9 codon is GTT (Val), than digestion with BshTI produces two DNA fragments, 17 and $74 \mathrm{bp}$ in length. If codon -9 is GCT (Ala), the amplified product not digested with this enzyme (Fig. 1).

The Ala allele and the Ala/Val genotype were the most common in healthy subjects (Table 2). The observed level of heterozygosity was $53.4 \%$. The observed genotype frequency was consistent with Hardy-Weinberg equilib- $\operatorname{rium} \mathrm{X}^{2}=2.0976$ and $\mathrm{G}-\mathrm{statistic}=2.1149, \mathrm{p}=0.3930 \pm$ 0.0154).

The frequencies of the Ala allele and the Ala/Ala genotype were significantly lower in patients with $\mathrm{DN}$ than in patients without DN whereas the frequency of the Val allele and the homozygous Val/Val genotype was significantly higher in patients with DN (Table 3).This suggests that the Ala(-9)Val dimorphism in the $M n-S O D$ gene is associated with neuropathy in type 1 diabetes mellitus. The Ala allele (odds ratio $=0.48,95 \% \mathrm{CI}$; 0.31-0.74) and the Ala/Ala genotype (odds ratio $=0.34$, 95\% CI; 0.17o.66) are associated with lower risk of DN development in than the Val allele (odds ratio $=2.09$, 95\% CI; $1.35^{-}$ 3.24 ) and the $\mathrm{Val} / \mathrm{Val}$ genotype (odds ratio $=5.10,95 \%$ CI; 1.77-14.69).

Table 2: Allele and genotype distribution of the Ala(-9)Val MnSOD and Arg2 I3Gly EC-SOD polymorphic markers in healthy subjects

\begin{tabular}{lccc}
\hline $\begin{array}{c}\text { Ala(-9) Val } \\
\text { Mn-SOD }\end{array}$ & $\begin{array}{c}\text { Frequency } \\
\mathrm{n}(\%)\end{array}$ & $\begin{array}{c}\text { Arg2/3Gly } \\
\text { EC-SOD }\end{array}$ & $\begin{array}{c}\text { Frequency } \\
\mathrm{n}(\%)\end{array}$ \\
\hline \multicolumn{4}{c}{} \\
Ala & \multicolumn{4}{c}{ Allele distribution } \\
Val & \multicolumn{1}{c}{$19(67.6)$} & Arg & $116(65.9)$ \\
Ala/Ala & $57(32.4)$ & Gly & $60(34.1)$ \\
Ala/Nal & Genotype distribution & \\
Val./Val & $36(40.9)$ & Arg/Arg & $34(38.6)$ \\
& $47(53.4)$ & Arg/Gly & $48(54.5)$ \\
& $5(5.7)$ & Gly/Gly & $6(6.8)$ \\
\hline
\end{tabular}

Table 3: Allele and genotype distribution of the Ala(-9)Val Mn-SOD polymorphic marker in type I diabetic patients with and without neuropathy

\begin{tabular}{|c|c|c|c|c|c|}
\hline \multirow[t]{2}{*}{ Group } & \multicolumn{2}{|c|}{$\begin{array}{l}\text { Allele frequency } \\
n(\%)\end{array}$} & \multicolumn{3}{|c|}{$\begin{array}{c}\text { Genotype frequency } \\
\text { n (\%) }\end{array}$} \\
\hline & Ala & Val & Ala/Ala & $\mathrm{Ala} / \mathrm{Val}$ & $\mathrm{Val} / \mathrm{Val}$ \\
\hline $\begin{array}{l}\text { Neuropathy } \\
(\mathrm{n}=82)\end{array}$ & $\begin{array}{l}83^{a} \\
(50.6)\end{array}$ & $\begin{array}{l}8 I^{\mathrm{b}} \\
(49.4)\end{array}$ & $\begin{array}{c}14^{c} \\
(17.1)\end{array}$ & $\begin{array}{c}55 \\
(67.0)\end{array}$ & $\begin{array}{l}13^{d} \\
(15.9)\end{array}$ \\
\hline $\begin{array}{l}\text { No neuropathy } \\
(\mathrm{n}=84)\end{array}$ & $\begin{array}{l}115 \\
(68.5)\end{array}$ & $\begin{array}{c}53 \\
(31.5)\end{array}$ & $\begin{array}{c}33 \\
(39.3)\end{array}$ & $\begin{array}{c}49 \\
(58.3)\end{array}$ & $\begin{array}{c}2 \\
(2.4)\end{array}$ \\
\hline
\end{tabular}

\footnotetext{
${ }^{a}$ Ala allele frequency was significantly lower in patients with diabetic neuropathy than in subjects without this complication (odds ratio $=0.48, \mathrm{p}=$ $\left.0.00067, P_{c}=0.00134\right) .{ }^{b}$ Val allele frequency was significantly higher in patients with diabetic neuropathy than in subjects without this complication (odds ratio $=2.10, p=0.00067, p_{c}=0.00134$ ). ${ }^{c}$ Ala/Ala genotype frequency was significantly lower in patients with diabetic neuropathy than in subjects without this complication (odds ratio $=0.34, p=0.00122, P_{c}=0.00366$ ). ${ }^{d} \mathrm{Val} / \mathrm{Val}$ genotype frequency was significantly higher in patients with diabetic neuropathy tha in subjects without this complication (odds ratio $=5.10, p=0.00219, p_{c}=0.00657$ ).
} 
Table 4: Allele and genotype distribution of the Arg2 I3Gly Mn-SOD polymorphic marker in type I diabetic patients with and without neuropathy

\begin{tabular}{|c|c|c|c|c|c|}
\hline \multirow[t]{2}{*}{ Group } & \multicolumn{2}{|c|}{$\begin{array}{l}\text { Allele frequency } \\
n(\%)\end{array}$} & \multicolumn{3}{|c|}{$\begin{array}{c}\text { Genotype frequency } \\
\text { n (\%) }\end{array}$} \\
\hline & Arg & Gly & Arg/Arg & Arg/Gly & Gly/Gly \\
\hline Neuropathy & 82 & 82 & 16 & 50 & 16 \\
\hline$(n=82)$ & $(50.0)$ & $(50.0)$ & $(19.5)$ & $(61.0)$ & $(19.5)$ \\
\hline $\begin{array}{l}\text { No neuropathy } \\
(\mathrm{n}=84)\end{array}$ & $\begin{array}{c}95 \\
(56.5)\end{array}$ & $\begin{array}{c}73 \\
(43.5)\end{array}$ & $\begin{array}{c}21 \\
(25.0)\end{array}$ & $\begin{array}{c}53 \\
(63.1)\end{array}$ & $\begin{array}{c}10 \\
(11.9)\end{array}$ \\
\hline
\end{tabular}

The Ile58Thr polymorphism of the Mn-SOD gene

The penultimate adenosine residue at 3 ' end of the reverse primer SOD2-58R used is not complemetary to the genomic sequence (5'-GATAGC-3'), creating an Eco32I restriction site (5'-GATATC- 3 ') during amplification if codon 58 is ATA (Ile) [26]. In this case, a 140-bp PCR product is produced, which yields two fragments, 20-bp and 120-bp in size, on digestion with Eco32I. If codon 58 is ACA (Thr allele) the amplified product not cleaved by this enzyme.

Eighty-seven of the 88 healthy subjects displayed the Ile/ Ile genotype, the remaining subject was heterozygous, Ile/Thr. All of the diabetic patients without complications were homozygous (Ile/Ile), as were all but one of the patients with $\mathrm{DN}$, the remaining patient being heterozygous. So, no association between the Ile58Thr polymorphism of the $M n-S O D$ gene and DN was observed in type 1 diabetic patients.

\section{The Arg2 I 3 Gly polymorphism of the EC-SOD gene}

The last guanosine residue at the 3 ' end of the reverse primer, SOD3-231R, displays a mismatch with the original sequence, 5'-CGGCGG-3', close to codon 213 of the $E C-S O D$ gene. This resulted (depending on the sequence) in creation of an Eco52I restriction site (5'-CGGCCG-3') in the PCR product [19]. If codon 213 was CGG (Arg), a 104-bp PCR product was obtained that yielded two DNA fragments of 23 and 81 bp in size on digestion with Eco52I. In contrast, if codon 213 was GGG (the Gly allele), the 104-bp product was not digested with the enzyme (Fig. 2).

The Arg allele was 1.9 times more frequent than the Gly allele in healthy subjects. Arg/Arg homozygotes were 5.7 times more frequent than Gly/Gly homozygotes (Table 2). The observed level of heterozygosity was 54.6\%. The observed genotype distribution was consisted with Har-

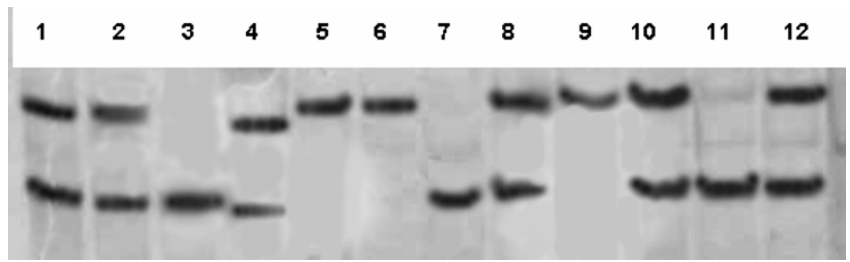

Figure 2

Restriction analysis of Arg2/3Gly polymorphism at the SOD3 gene. Lanes I-3, 5-12: II samples after digestion with Eco52I; lanes 3, 7, and II, Arg/Arg genotype; lanes I, 2, 8, I0, and 12, Arg/Gly genotype; lanes 5, 6, and 9, Gly/Gly genotype. Lane 4: molecular weight DNA marker pBR322/Mspl 90- and 76-bp DNA fragments are shown.

dy-Weinberg equilibrium $\left(X^{2}=1.9495\right.$ and G-statistic $=$ $1.9614, p=0.3980 \pm 0.0155)$. No significant difference in allele and genotype distribution was found between DN patients and patients without DN (Table 4). Thus, Arg213Gly substitution in the EC-SOD gene is not associated with nerve lesions in type 1 diabetes mellitus.

\section{Discussion and Conclusions}

A number of techniques have been described for detection of the Ala (-9)Val Mn-SOD gene dimorphism. One such method is PCR amplification of the polymorphic region, followed by BsaWI treatment (i.e., PCR/restriction fragment length polymorphism, PCR/RFLP) [16]. Another method is single-strand conformational polymorphism (SSCP) analysis of the product amplified by PCR [9]. A third method is two-step PCR using allele-specific primers for a second round of PCR [10]. Finally, the PCR product can be hybridized with allele-specific oligonucleotide (ASO) probes [13]. We have decided to use restriction endonuclease BshTI for detection of the Ala(-9)Val polymorphism because this enzyme is commercially available in Russia whereas BsaWI is not. Our detection method has advantages over other techniques because is 
no need to carry out using the second round of PCR or laborious procedure of SSCP analysis after PCR amplification. Our molecular assay involves use of the mismatchPCR/RFLP approach, which can be applied to the detection of any polymorphic single base substitution that fails to create or eliminates restriction sites. This rapid assay requires no special equipment or expertise. The use of a mismatch PCR primer makes it possible to create a restriction site in the amplified product only in the presence of the polymorphic base. This approach has been used to genotype the M235T variant of angiotensinogen [27] and the C1166T nucleotide variation in the angiotensinogen II (type 1) receptor gene [28].

The Ala allele of the $M n-S O D$ gene was more widespread than the Gly allele in healthy Russian subjects. This feature is common to all other Caucasian population samples tested (Germans, Swedes, Lithuanians, Finns, and Saamis) $[16,29]$. In contrast, the frequency of the Ala variant is significantly lower in Asian populations (Chinese and Japanese) than in most European populations $[9,11,13,29]$.

The Ala/Val variation in the Mn-SOD leader signal affects the processing efficiency of the enzyme. The conformations of the Ala-type and Val-type leader signals have been predicted: the Ala form has an alpha-helical structure, a common conformation for mitochondrial leader signals, whereas the Val form may change its conformation from alpha-helix to beta-sheet starting from the position 16 due to amino acid substitution [9]. The Val form is less efficiently transported into mitochondria than the Ala form of the enzyme [9]. Poor signal sequence recognition by a receptor in the inner mitochondrial membrane may result in mistargeting. In addition, inefficient cleavage of a particular signal may reduce the level of enzymatic activity of an imported protein, such as MnSOD, within the mitochondrial compartment [30]. Studies of processing have suggested basal level of the MnSOD activity may be highest for Ala/Ala, followed by Ala/ Val, and then Val/Val [13].

The Val variant of the Mn-SOD may be present in a lower concentration in mitochondria. If this is the case, then homozygous Val/Val should have lower resistance to oxidative stress than patients with other Mn-SOD variants. Such lower resistance is a common feuature of diabetes mellitus and various ageing and neurological disorders. This study showed that the Val $M n-S O D$ allele predisposed patients to the development of $\mathrm{DN}$ in type 1 diabetes mellitus. Inefficient targeting of Mn-SOD may leave mitochondria inabequately defended against superoxide radicals. This may lead to protein oxidation, mitochondrial DNA mutations and damage, common in the pathogenesis of diabetic neuropathy $[2,3]$ and neurodegenerative disorders such as Alzheimer and Parkinson's disease [31].

The Ala/Val dimorphic site is located within exon 2 of the $M n-S O D$ gene. Knock-out mice lacking exons 1 and 2 of $M n-S O D$ have been found to display progressive motor disturbances due to neuronal degeneration [32]. This observation provides future evidence for the involvement of the SOD2 gene in neuropathology.

Another functional polymorphism of the $M n-S O D$ gene, Ile58Thr in exon 3, affects the stability of the Mn-SOD tetramer and reduces the activity of the enzyme [14]. However, the Thr allele has been shown to be extremely rare. Our data consistent with those of Grasbon-Frodl et al. [16] who detected the Ile/Ile variant in only 63 randomly selected German subjects. The Ile58Thr variation of Mn-SOD probably not involved in DN pathogenesis. However this mutation is more likely to be involve in hereditary aging-related neurodegenerative disease, as shown by the finding that leukocytes lose the ability to induce Mn-SOD expression in response to increases in reactive oxygen species levels in tissue, in subjects over the age of 55 years [14]. Thus, older people with genetic defects in the four-helix bundle tetrameric interface of Mn-SOD may be especially prone to degenerative diseases.

An Arg213Gly substitution in the extracellular isoform (EC-SOD) does not affect enzymatic activity but does affect the amount of the enzyme on the external endothelial cell surface [33]. The Arg variant of EC-SOD is the most common in varios populations $[17,18]$ including the Russian population (Table 2). Arginine-to-glycine substitution occurs in the center of the carboxyl-terminal cluster of positively charged amino acid residues defining the heparin-binding domain [17]. This amino acid substitution results in a higher level of dissociation of the enzyme from the cell surface into serum. Thus, the lower levels of EC-SOD on vascular walls must be positively correlated with a higher risk of progression of oxidative stress in affected patients with the Gly/Gly genotype. However, this finding was not supported by our data which showed a lack of association of the polymorphic marker with diabetic neuropathy. Such a relationship has been found only in Japanese patients with non-diabetic form of neuropathy resulting from massive amyloid deposition in nervous tissues [22].

Finally, we have no comparative data concerning the role of genetic factors directly related to oxidative stress in DN formation and progression. It would be of value to compare our findings with those of similar association studies in other populations. 


\section{Acknowledgements}

We thank Dr. I.A.Strokov for the collection of blood samples.

\section{References}

I. Hunt JV, Wolff SP: Oxidative glycation and free radical production: a causal mechanism of diabetic complications. Free Radic Res Commun 1991, 12-13:115-123

2. Low PA, Nickander KK, Tritschler $\mathrm{H}$ : The roles of oxidative stress and antioxidant treatment in experimental diabetic neuropathy. Diabetes 1997, 46:S38-S42

3. Zhu M, Spink DC, Yan B, Bank S, DeCaprio AP: Formation and structure of cross-linking and monomeric pyrrole autoxidation products in 2,5-hexanedione-treated amino acids, peptides, and protein. Chem Res Toxicol 1994, 7:55I-558

4. Cameron NE, Cotter MA: Metabolic and vascular factors in the pathogenesis of diabetic neuropathy. Diabetes I997, 46:S3 I-37

5. Nagamatsu M., Nickander KK, Schmelzer JD, Raya A, Wittrock DA, Tritschler H, Low PA: Lipoic acid improves nerve blood flow, reduces oxidative stress, and improves distal nerve conduction in experimental diabetic neuropathy. Diabetes Care 1995, I 8: I I60-1 |67

6. Van Dam PS, Van Asbeck BS, Bravenboer B, Van Oirschot JF, Marx J], Gispen WH: Nerve conduction and antioxidant levels in experimentally diabetic rats: effects of streptozotocin dose and diabetes duration. Metabolism 1999, 48:442-447

7. Martinez-Blasco A, Bosch-Morell F, Trenor C, Romero FJ: Experimental diabetic neuropathy: role of oxidative stress and mechanisms involved. Biofactors 1998, 8:41-43

8. Yan H, Harding J]: Glycation-induced inactivation and loss of antigenicity of catalase and superoxide dismutase. Biochem J 1997, 328:599-605

9. Shimoda-Matsubayashi S, Matsumine H, Kobayashi T, Nakagawa-Hattori Y, Shimizu Y, Mizino Y: Structural dimorphism in the mitochondrial targeting sequence in the human manganese superoxide dismutase gene. Biochem Biophys Res Commun 1996, 226:56I-565

10. Rosenblum JS, Gilula NB, Lerner RA: On signal sequence polymorphisms and diseases of distribution. Proc Natl Acad. Sci USA 1996, 93:447|-4473

II. Hori H, Ohmori O, Shinkai T, Kojima H, Okano C, Suzuki T, Nakamura J: Manganese superoxide dismutase gene polymorphism and schizophrenia. Relation to tardive dyskinesia. Neuropsychopharmacol 2000, 23:170-177

12. Van Landeghem GF, Tabatabaie P, Beckman G, Beckman L, Andersen PM: Manganese-containing superoxide dismutase signal sequence polymorphism associated with sporadic motor neuron disease. Eur J Neurol 1999, 6:639-644

13. Hiroi S, Harada H, Nishi H, Satoh M, Nagai R, Kimura A: Polymorphisms in the SOD2 and HLA-DRBI genes are associated with nonfamilial idiopathic dilated cardiomyopathy in Japanese. Biochem Biophys Res Commun 1999, 261:332-339

14. Borgstahl GE, Parge HE, Hickey MJ, Johnson MJ, Boissinot M, Hallewell RA, Lepock JR, Cabelli DE, Tainer JA: Human mitochondrial manganese superoxide dismutase polymorphic variant Ile58Thr reduces activity by destabilizing the tetrameric interface. Biochemistry 1996, 35:4287-4297

I5. Checkoway H, Farin FM, Costa-Mallen P, Kirchner SC, Costa LG: Genetic polymorphisms in Parkinson's disease. Neurotoxicology 1998, 19:635-643

16. Grasbon-Frodl EM, Kosel S, Riess O, Muller U, Mehraein P, Graeber $\mathrm{MB}$ : Analysis of mitochondrial targeting sequence and coding region polymorphisms of the manganese superoxide dismutase gene in German Parkinson disease patients. Biochem Biophys Res Commun 1999, 255:749-752

17. Sandstrom J, Nilsson P, Karlsson K, Marklund SL: I0-fold increase in human plasma extracellular superoxide dismutase content caused by a mutation in heparin-binding domain. J Biol Chem 1994, 269:19163-19166

18. Yamada H, Yamada Y, Adachi T, Goto H, Ogasawara N, Futenma A, Kitano M, Hirano K, Kato K: Molecular analysis of extracellularsuperoxide dismutase gene associated with high level in serum. Jpn J Hum Genet 1995, 40:177-184

19. Yamada H, Yamada Y, Adachi T, Goto H, Ogasawara N, Futenma A, Kitano M, Miyai H, Fukatsu A, Hirano K, Kakumu S: Polymorphism of extracellular superoxide dismutase (EC-SOD) gene: rela- tion to the mutation responsible for high EC-SOD level in serum. Jpn J Hum Genet 1997, 42:353-356

20. Adachi T, Wang XL: Association of extracellular-superoxide dismutase phenotype with the endothelial constitutive nitric oxide synthase polymorphism. FEBS Lett 1998, 433:166-168

21. Marklund SL, Nilsson P, Israelsson K, Schampi I, Peltonen M, Asplund K: Two variants of extracellular-superoxide dismutase: relationship to cardiovascular risk factors in an unselected middle-aged population. I Intern Med 1997, 242:5-14

22. Sakashita N, Ando Y, Marklund SL, Nilsson P, Tashima K, Yamashita T, Takahashi K: Familial amyloidotic polyneuropathy type I with extracellular superoxide dismutase mutation: a case report. Hum Pathol 1998, 29: I 169-II72

23. Mathew CGP: The isolation of high molecular weight eukaryotic DNA. In Methods of Molecular Biology. Edited by Walker J. Vol. 2. Humana Press, I 984, 3 I-34

24. Budowle B, Chakraborty R, Giusti AM, Eisenberg AJ, Allen RC: Analysis of the VNTR locus DIS80 by PCR followed by high-resolution PAGE. Am J Hum Genet I99|, 48: I 37-I44

25. Roff DA, Bentzen P: The statistical analysis of mitochondrial DNA polymorphisms: $\mathrm{X} 2$ and the problem of small samples. Mol Biol Evol I 989, 6:539-545

26. Church SL, Grant JW, Meese EU, Trent JM: Sublocalization of the gene encoding manganese superoxide dismutase (MnSOD/ SOD2) to 6 q25 by fluorescence in situ hybridization and somatic cell hybrid mapping. Genomics 1992, I 4:823-825

27. Caulfield $M$, Lavender $P$, Farral $M$, Nunroe $P$, Lawson $M$, Turner $P$, Clark AJl: Linkage of the angiotensinogen gene to essential hypertension. N Engl J Med 1994, 330:1629-1633

28. Hingorani A, Brown MJ: A simple molecular assay for the CI 166 variant of the angiotensin II type I receptor gene. Biochem $\mathrm{Bi}$ ophys Res Commun 1995, 2 I 3:725-729

29. Van Landeghem GF, Tabatabaie P, Kucinskas V, Saha N, Beckman G: Ethnic variation in the mitochondrial targeting sequence polymorphism of MnSOD. Hum Hered 1999, 49:190-193

30. Shimoda-Matsubayashi S, Hattori Y, Matsumine H, Shinohara A, Yoritaka $\mathrm{A}$, Mori $\mathrm{H}$, Kondo $\mathrm{T}$, Chiba M, Mizuno $\mathrm{Y}$ : MnSOD activity and protein in a patient with chromosome 6-linked autosomal recessive parkinsonism in comparison with Parkinson's disease and control. Neurology 1997, 49:1257-1262

31. Jenner P: Oxidative stress in Parkinson's disease and other neurodegenerative disorders. Pathol Biol (Paris) 1996, 44:57-64

32. Melov S, Schneider J, Day B, Hinerfield D, Coscun P, Mirra SS, Crapo ID, Wallace DC: A novel neurological phenotype in mice lacking mitochondrial superoxide dismutase. Nat Genet 1998, 18:159-163

33. Adachi T, Yamada H, Yamada Y, Morihara N, Yamazaki N, Murakami T, Futenma A, Kato K, Hirano K: Substitution of glycine for arginine-2 I 3 in extracellular-superoxide dismutase impairs affinity for heparin and endothelial cell surface. Biochem J 1996, 3 | 3:235-239

\section{Pre-publication history}

The pre-publication history for this paper can be accessed here:

http://www.biomedcentral.com/content/backmatter/ 1471-2350-2-4-b1.pdf 